DOI: $10.31866 / 2410-1915.22 .2021 .235907$

UDC 004.8:7.01/.09

\title{
ARTIFICIAL INTELLIGENCE AS A TOOL FOR CREATING AND ANALYSING WORKS OF ART
}

\author{
Yuliia Trach \\ $P h D$ in Education, \\ ORCID:0000-0003-2963-0500,0411@ukr.net, \\ Kyiv National University of Culture and Arts, \\ 36, Ye. Konovaltsia St., Kyiv, 01133, Ukraine
}

\section{For citations:}

Trach, Y. (2021). Artificial Intelligence As A Tool For Creating And Analysing Works Of Art. Culture and Arts in the Modern World, 22, 164-173. https://doi.org/10.31866/2410-1915.22.2021.235907.

The purpose of the article is to reveal the specifics of creating new works of art using artificial intelligence technologies. The research methodology is based on the application of the dialectical method with its principles of consistency, development and unity of polarities since artificial intelligence as a complex sociocultural phenomenon provides unambiguous definitions and at the same time forces to interpret its essence and relations dialectically to its application field. The scientific novelty of the obtained results lies in the fact that artificial intelligence is considered a component of artistic creativity, one of which is to introduce technical innovations in human culture. Conclusions. The article focuses on the fact that the artificial intelligence issue is beyond the cultural discourse, and separating the artificial intelligence issue from culture inevitably leads to a simplified understanding. It is noted that the relevance of cultural research of artificial intelligence (AI) is determined by the spread of symbiotic forms of interaction between the user and global software, which requires not so much evaluating and correcting the negative consequences of the spread of technology but rather the development of meta technology to prevent them. For its part, the reflection of culture, when the latter rejects the ideas of the techno apocalypse and the rise of machines, can give an impetus to the emergence of new meanings and perspectives for man and culture. Finally, the article provides examples of the AI technologies use (in particular, Gan and CAN) in contemporary art. However, the more AI technologies are used in creating works of art, the more valuable an idea or a concept becomes. Today, when the performance and physical implementation of a project can be "shifted" to AI, new ideas become the main driving force in the development of art. The ideas generation may become the primary option not of a person but of a "machine", which, once again, proves the correctness of the assumption that every year such human abilities as creativity, generation of new extraordinary ideas and solutions will become more valuable. And the routine performance, the analysis of big data, etc., are the tasks for machines, and they perform this work better than a human.

Keywords: artificial intelligence; neural network; machine learning algorithm; work of art

(C) Yuliia Trach, 2021

The article was received by the editorial office: 21.04 .2021 


\section{Introduction}

Today, in Ukraine, there is a discussion of the road map for implementing the Concept of AI development in Ukraine, approved by the Order of the Cabinet of Ministers of Ukraine on December 2, 2020 (Kabinet Ministriv Ukrainy, 2020). The adoption of the national Concept is highly relevant, considering that in the context of the scientific and technological revolution, AI can become a powerful driving force for activating significant socioeconomic and sociocultural changes. Several dozen of leading countries in the world, including the United States, China, the Netherlands, France, Japan, the United Arab Emirates, etc., have already adopted corresponding road maps, recognising the importance of strategic vision in this direction that takes into account the importance of AI for the national economy, social relations and security. AI allows getting results similar to the effects of human intellectual activity in such areas as computer vision, recommender systems and intelligent decision support systems, natural language processing, speech recognition and synthesis, and other promising methods and technologies of artificial intelligence. AI is changing modern society radically: from the financial sector, industry, power engineering and agriculture to the educational and cultural spheres. According to the forecasts of the international consulting company Deloitte, the volume of investment in artificial intelligence in 2021 will reach 57.6 billion dollars (Deloitte, 2017). The profit from its use in specific sectors of the global economy, according to McKinsey Global Institute analysis, will be from 3.5 to 5.8 trillion dollars (Chui et al, 2018).

Despite the colossal rate of AI spread worldwide, its discourse is still outside the boundaries of cultural studies, being formed in the interdisciplinary field of computer sciences. One of the main directions of understanding AI is based on the statement that artificial systems should not repeat biological systems in their structure and functioning (J. McCarthy). The paradigm of biocomputing is the opposite (W. McCulloch) - a combination of information, molecular technologies and biochemistry, which originates from the environment of developers of computers and computer software. Meanwhile, exploring the world only through the prism of technical sciences or trying to solve global problems only with the help of technology, humanity runs the risk of making typical mistakes that slow down progress and increase inequality. The separation of the AI problem from culture leads inevitably to a simplified understanding of the latter. At the same time, the relevance of cultural research of AI is determined by the spread of symbiotic forms of interaction between the user and global software, which requires not evaluation and correction of the negative consequences of the spread of technologies but the development of meta technology to prevent them. The inclusion of artificial intelligence in the sphere of cultural discussion will allow avoiding technicism and actualism, including the issue of the AI carrier.

Recent research and publications analysis. The numerous works of foreign researchers are devoted to the study of artificial intelligence: $\mathrm{N}$. Bostrom (2016), G. F. Luger (2003), J. Markoff (2020), S. Russell and P. Norvig (2006), etc., 
who studied strategies and methods for the solution of complex problems in the theory of artificial intelligence, stages, threats and strategies of the latter, and so on from modern positions. Unfortunately, there are not many works devoted to the humanitarian aspects of AI research in Ukraine. In particular, the philosophical analysis of AI systems is contained in A. Shvyrkov's article (2005), the possible prospects for AI are described in the articles by V. Karpenko (2011), A. Matviichuk (2011), the history and prospects of AI development are presented by M. Yefremov and Yu. Yefremov (2008). However, there are no scientific studies in which AI would be considered an element of culture, a tool for sociocultural transformations, and a means of creating something fundamentally new in modern culture. However, the humanitarian reflection of the artificial intelligence problems will allow realising its full cultural potential to comprehend it in a timely and consistent manner using the methodology of culturological research. It is highly relevant since AI is undoubtedly a product and tool of cultural development. Therefore, when the latter rejects the ideas of the techno apocalypse and the rise of machines, the reflection of culture can give an impetus to the emergence of new meanings and prospects for humans and culture.

\section{Purpose of the article}

The purpose of the article is to reveal the specifics of creating new works of art using artificial intelligence technologies, to find out the potential of artificial intelligence as a component of artistic creativity, one of which is to introduce technical innovations in human culture.

\section{Main research material}

The interaction of AI technologies and the cultural sector is far from perfect - it is unbalanced and disorganised, associated with existential and civilisational challenges. However, artificial intelligence already exists and exists in a culture that responds to it and builds its relationships. The calls to stop the "blind rush" for the digital future finally and start making more reasonable decisions about when and for what purpose to use the achievements in IT are heard more often. We are talking about the situation when public opinion is inclined to believe that an electronic judge can be more effective than a real judge. However, it is only when a case under consideration is not related to the interpretation of the law, and a "digital doctor" can make a more accurate diagnosis. E-services for the selection of goods in online stores have proved their effectiveness long ago and in the tourism, hotel business, and transportation organisation. Therefore the removal of the human factor in these areas seems quite possible. In the arts sector, the situation is similar - artificial intelligence "works its way" confidently: today you can watch psychedelic paintings written by artificial intelligence, a Microsoft Project on image generation has already been developed based on works of art (for example, the painting The Next Rembrandt), the MosAIc system for finding relationships between art objects 
from different cultures and eras and the algorithm that retouches photos in real time. According to Intel Corporation data, artificial intelligence has already been used to create experimental movie trailers, scripts for short films and musical compositions. AI technologies can perform not only routine tasks but also inspire the creation of something fundamentally new.

In creating works of art, a neural network or machine learning algorithm is called artificial intelligence. A neural network is a multitude of simple interconnected elements formed into a primitive resemblance of a brain. According to the specified task, the neural network analyses the works uploaded to its database, recognise images, techniques, style signs, and then uses the acquired knowledge to create, for example, paintings. The machine learning algorithm can find dependencies, features and rules in each multitude of loaded objects whether it's paintings, music or poetry. Having processed a large amount of data, the neural network summarises them and concludes in various ways. What precisely the algorithm will learn is determined by a data analysis specialist: either to write poems that are similar in foot and vocabulary to those uploaded to the database, or imitate a particular artist or compile the style of several at once. It is no accident that contemporary art based on artificial intelligence technologies has attracted a lot of attention from the general public. A clear example is the sale of the canvas Edmond De Belamy (Obvious, 2018) created by the French art group Obvious at Christie's auction for 432.5 thousand dollars in 2018. The emergence of Edmond De Belamy and the fact of selling a painting created by artificial intelligence at a prestigious art auction is undoubtedly a readymade in the history of art, in fact, a milestone thing, which Malevich's Black Square or Marcel Duchamp's Fountain were at their time. A blurred portrait of a person created using Generative Adversarial Network (GAN) and printed on a $700 \times 700 \mathrm{~mm}$ canvas is depicted in the painting. GAN technology is based on the use of two neural networks, one of which generates pseudorandom images from a specified set of distributions, and the second (CNN discriminator) determines the plausibility of the image based on the training set. CNN (Convolutional Neural Networks) is a binary classifier and tries to answer the question: "Is the sample created by a human?". If the answer is no, then the example is marked as unsuccessful - in this way, the network learns to choose the correct option from a set of fake and human-created images. The neural network used to create the painting Edmond De Belamy was trained on 15,000 portrait works painted between the $14^{\text {th }}$ and the $20^{\text {th }}$ centuries.

Artists also use GAN technology to transform and improve their pencil sketches on paper. For example, a visual artist and software engineer Helena Sarin uses GAN to create new models and new data sets ("Helena Sarin", n.d.). Italian artist Davide Quayola uses Creative Adversarial Networks technology (CAN), thanks to which he was able to recreate "conditions similar to classical impressionist landscapes". The artist used "an extensive technological apparatus to capture the subtle nuances of reality beyond human perception" (Quayola, 2017). His project Jardins d'eté consists of a series of 4K-resolution digital video paintings inspired by gardens of Château de Chaumont-sur-Loire. A wide range of floral compositions manipulated by high winds is filmed at 
night in ultra-high definition. Quayola edits his videos with complex computational analyses of motion, composition, and colour schemes which become the foundation for creating new digital paintings. In Jardins d'eté, natural landscapes are observed and seen through the "eye" of a machine and then reinterpreted using new methods of visual synthesis (Quayola, 2017). Thus, the generation of random images in CAN technology adds spontaneity to the creativity of artificial intelligence and allows taking a step forward in comparison with deep stylisation. Modern society has "come" to a new era of creativity, when $\mathrm{AI}$ and the artist become co-authors, complementing each other in those areas and "skills" where they are the most powerful.

The sculptures created by artificial intelligence are not as popular as paintings, but this application of AI technologies is also developing quite actively. AI is mainly used either to build a GAN layout or directly to create a 3D model. For example, Scott Eaton's sculpture, which debuted at the exhibition Artist + AI: Figures \& Form in the Age of Intelligent Machines ("Scott Eaton", 2019) (London, 2019), was created in collaboration with artificial intelligence tools that translate drawings into three-dimensional form. Another example is the sculpture Dio of New York artist Ben Snell, to create which machine learning algorithms are used to scan and digest a database of historical artworks of world art, including more than a thousand works of classical sculpture (such as the famous Discobolus and Michelangelo's David), and then reproduced the data obtained with the output guided by the artist. When the creation of the model was finished, Ben Snell disassembled the computer and ground its enclosure, hard drive and graphics processing unit into dust, mixed it with resin and poured this mixture into a hollow mould cast on a 3D printer ("Ben Snell", n.d.).

AI creates not only unique works of art - projects with the use of it become more visible, more functional and more promising, proving the effectiveness of the use of artificial intelligence technologies for different purposes and in various spheres of human activity. Thus, the researchers from Lawrence Technological University (the USA), K. Napier and L. Shamir (2018), published the results of their research on quantitative analysis of the tonality of lyrics in popular music. Based on the fact that popular music has changed significantly in recent decades compared to previous eras, the researchers analysed the sentiments expressed in the songs of the Billboard Hot 100 - the weekly chart of the 100 most popular songs in the United States between 1951 through 2016, that is 6150 tracks. The obtained results indicate a clear and statistically significant change in sentiments expressed through popular music lyrics, generally towards a more negative tone eloquently: there became much more anger, disgust, fear, sadness than joy, confidence and openness expressed in the lyrics of pop songs. Naturally, sociologists, psychologists, culturologists, etc., draw conclusions from this study. Still, AI has fulfilled its task - it has distinguished and analysed information from a massive array of unstructured data, for which a person would have to spend a lot of time and resources.

Another brilliant example of the expansion of the possibilities of art with the help of AI technologies is the use of innovative applications, such as CoArt, with which it is possible to "communicate". Namely, "with the help" of this applica- 
tion, the National Museum in Wroclaw hosted Michael Willmann's exhibition. Opus Magnum in 2020, which represented one of the artist's most intriguing paintings Paradise ("IBM Watson", n.d.). The visitor is issued a smartphone with a headset and, by using the CoArt mobile application, they can ask questions and receive answers in Polish from the so-called "electronic guide". The CoArt project is the culmination of over year-long cooperation of the IBM Services team of experts with art historians, experts from the National Museum, and educators and students from the Academy of Fine Arts in Wroclaw. The IBM Services team was responsible for building the solution, ongoing maintenance, and developing the app on IBM's cloud which, in partnership with IBM's Client Innovation Center in Wroclaw, included training Watson (an IBM supercomputer which main task is to understand questions posed in natural language and answer them using AI) to respond to questions in Polish. The production launch of the project was preceded by months of thorough quality tests conducted by the IBM and Museum project teams - starting with building a knowledge base about the painting with certain categories and questions that were tested with Watson's AI to provide the best answer for visitors to the painting. Since this app is developed using AI technologies, it can learn based on the questions asked to it by each visitor; the app can constantly improve the quality and accuracy of results.

There are no doubts that a neural network's analytical abilities are higher than any experienced art critic. It marks all the most minor details and features of the work and compares them with each other. But, despite this, AI is entirely unable to distinguish meanings and create a coherent narrative. AI can generate a verse similar to the work of a particular poet, but it doesn't understand what it's about. It's the same with painting - AI can analyse the technique of a particular artist, find frequently encountered images, imitate them and send them to print. Still, AI does this mechanically, unconsciously, at least for now. Today, AI is only a tool that a person operates: it prepares the base for training a neural network, sets the parameters according to which it will create, selects results. The paintings, created using AI technologies, can be considered works of art, since today in modern art, it is not the visualisation of something important but the act itself and the fact of this visualisation. However, the artistic significance of these paintings should not be overestimated. This is the first. Secondly, in the situations when artists use neural networks and machine learning algorithms, it is important to realise that AI can create something just like a person, but, at the same time, it is capable of extraordinary, non-obvious opportunities and solutions. But at the same time, the "smartest" neural network does not know why it does its job. The smartest person cannot process large amounts of data on an equal footing with a computer, so the only correct solution in this situation is to work in symbiosis and solve problems together, whether it is business, science or art.

\section{Conclusions}

Thus, new digital technologies in general and artificial intelligence in particular change radically the nature of "traditional" technical professions and 
affect creative processes, penetrating the artistic environment and causing the emergence of such phenomenon as digital art. For example, without digital processing and computer effects, it is impossible to imagine either modern cinema or music - today, a "computer" has become a canvas, a brush, and a musical instrument literally. Perhaps, the next stage in the development of digital art will be the use of the "computer" not as a tool for the implementation of human ideas but as an independent creative entity: Neural Style Transfer, Deep Dream technologies allow objects creation that does not differ much from human products. Nevertheless, even though the gap between AI and humans is narrowing rapidly, so far, it is namely the person, who sets up the model, selects training examples and uses technology for creativity.

Artificial intelligence provides extraordinary tools for creativity and a new, unusual experimental field for artists in the visual arts and entertainment industry (Game and Film Design, computer-generated imagery (CGI), etc.). However, the more artificial intelligence technologies are used in creating works of art, the more valuable an idea or a concept becomes. Today, when the performance and physical implementation of a project can be "shifted" to AI, new ideas become the main driving force in the development of art. The ideas generation may become the primary option not of a person but of a "machine", which, once again, proves the correctness of the assumption that every year such human abilities as creativity, generation of new extraordinary ideas and solutions will become more valuable. And the routine performance, the analysis of big data, etc., are the tasks for machines, and they perform this work better than a human.

In the future, it is necessary to identify and analyse the dynamics of changes in AI occurring within the general cultural processes of modern society, considering the pace of complexity and the scale of the spread of artificial intelligence technologies.

\section{References}

Ben Snell. (n.d.). http://bensnell.io/ [in English].

Bostrom, N. (2016). Iskusstvennyi intellekt. Etapy. Ugrozy. Strategii [Superintelligence. Paths, Dangers, Strategies] (S. Filin, Trans.). Mann, Ivanov i Ferber [in Russian].

Chui, M., Manyika, J., Miremadi, M., Henke, N., Chung, R., Nel, P., \& Malhotra, S. (2018, April 17). Notes From the AI Frontier: Applications and Value of Deep Learning. McKinsey Global Institute. https:/www.mckinsey.com/featured-insights/ artificial-intelligence/notes-from-the-ai-frontier-applications-and-value-ofdeep-learning [in English].

Deloitte. (2017). Machine Learning: Things are Getting Intense. https:// www2.deloitte.com/content/dam/Deloitte/global/Images/infographics/ technologymediatelecommunications/gx-deloitte-tmt-2018-intense-machinelearning-report.pdf [in English].

Helena Sarin. (n.d.). AIArtists. https://aiartists.org/helena-sarin [in English].

IBM Watson AI in the National Museum in Wroclaw. (n.d.). National Museum in Wroclaw. https://mnwr.pl/en/ibm-watson-ai-in-the-national-museum-in-wroclaw/ [in English]. 
Kabinet Ministriv Ukrainy. (2020 , December, 2). Pro skhvalennia Kontseptsii rozvytku shtuchnoho intelektu $v$ Ukraini [About Approval of the Concept of Development of Artificial Intelligence in Ukraine]. Order (№ 1556-r.). https://www.kmu. gov.ua/npas/pro-shvalennya-koncepciyi-rozvitku-shtuchnogo-intelektu-vukrayini-s21220 [in Ukrainian].

Karpenko, V. (2011). Hipotetychne maibutnie universalnoho shtuchnoho intelektu [Hypothetical Future of Universal Artificial Intelligence]. Filosofiia nauky: tradytsii ta innovatsii, 1(3), 57-64 [in Ukrainian].

Luger, G. F. (2003). Iskusstvennyi intellekt. Strategii i metody resheniya slozhnykh problem [Artificial Intelligence. Structures and Strategies for Complex Problem Solving] ( $4^{\text {th }}$ ed.). Vil'yams [in Russian].

Markoff, Dzh. (2020). Homo Roboticus? Lyudi i mashiny v poiskakh vzaimoponimaniya [Homo Roboticus? People and Machines in Search of Mutual Understanding] (S. Makharadze \& V. Ionov, Trans.). Al'pina Pablisher [in Russian].

Matviichuk, A. (2011). Mozhlyvosti ta perspektyvy stvorennia shtuchnoho intelektu [Opportunities and Prospects for Creating Artificial Intelligence]. Visnyk of the National Academy of Sciences of Ukraine, 12, 36-51 [in Ukrainian].

Napier, K., \& Shamir, L. (2018). Quantitative Sentiment Analysis of Lyrics in Popular Music. Journal of Popular Music Studies, 30(4), 161-176. https://doi.org/10.1525/ jpms.2018.300411 [in English].

Obvious. (2018). Edmond De Belamy. https://obvious-art.com/portfolio/edmond-debelamy/ [in English].

Quayola, D. (2017). "Jardins d'Été" ["Summer Gardens"]. Domain of Chaumont-surLoire. https://domaine-chaumont.fr/en/centre-arts-and-nature/archives/2017art-season/davide-quayola [in French].

Rassel, S., \& Norvig, P. (2006). Iskusstvennyi intellekt: sovremennyi podkhod [Artificial Intelligence: A Modern Approach] (K. A. Ptitsyn, Trans.). Vil'yams [in Russian].

Scott Eaton Artist+AI: Figures \& Form in the Age of Intelligent Machine. (2019). LUXlife. https://www.lux-review.com/scott-eaton-artistai-figures-form-in-the-age-ofintelligent-machines/ [in English].

Shvyrkov, O. (2005). Fenomen shtuchnykh intelektualnykh system: filosofskyi pohliad [The Phenomenon of Artificial Intelligent Systems: a Philosophical View]. Multiversum. Philosophical almanac, 47, 193-201 [in Ukrainian].

Yefremov, M. F., \& Yefremov, Yu. M. (2008). Shtuchnyi intelekt, istoriia ta perspektyvy rozvytku [Artificial Intelligence, History and Prospects of Development]. Journal Zhytomyr State Technological University. Series: Technical Sciences, 2(45), 123-127 [in Ukrainian]. 


\section{ШТУЧНИЙ ІНТЕЛЕКТ ЯК ІНСТРУМЕНТ ТВОРЕННЯ ТА АНАЛІЗУ ТВОРІВ МИСТЕЦТВА}

\section{Трач Юлія Василівна}

Кандидат педагогічних наук, ORCID: 0000-0003-2963-0500,0411@ukr.net, Київський національний університет культури і мистецтв, Київ, Україна

Мета статті - розкрити специфіку створення нових творів мистецтва за допомогою технологій штучного інтелекту. Методологія дослідження грунтується на застосуванні діалектичного методу з його принципами системності, розвитку і єдності полярностей, оскільки штучний інтелект як складний соціокультурний феномен спонукає до формулювання однозначних визначень і водночас змушує до діалектичного трактування його сутності і відношень до сфер його застосування. Наукова новизна одержаних результатів полягає в тому, що штучний інтелект розглянуто як складник художньої творчості, одне із завдань якого полягає у введенні технічних новацій у сферу людської культури. Висновки. Звернено увагу на перебування поза культурологічним дискурсом проблематики штучного інтелекту, тоді як відокремлення проблеми штучного інтелекту від культури неминуче призводить до спрощеного розуміння останньої. Наголошено, що актуальність культурологічного дослідження штучного інтелекту визначається поширенням симбіозних форм взаємодії користувача і глобального програмного забезпечення, що вимагає не стільки оцінювання та виправлення негативних наслідків розповсюдження технологій, скільки вироблення метатехнології з їх попередження. Зі свого боку рефлексія культури, коли остання відкидає ідеї техноапокаліпсису і повстання машин, може дати поштовх до виникнення нових сенсів і перспектив для людини і культури. Наведено приклади застосування технологій (зокрема, GAN та CAN) штучного інтелекту у сучасному мистецтві. Зроблено висновок, що чим більше у процесі створення творів мистецтва використовуються технології штучного інтелекту, тим більше зростає цінність ідеї, концепції. Сьогодні, коли виконання, фізичну реалізацію проєкту можна «перекласти» на штучний інтелект, саме нові ідеї стають основною рушійною силою в розвитку мистецтва. Генерування ідей може стати головною функцією не людини, а «машини», що вкотре доводить правильність припущення, що з кожним роком більш цінними ставатимуть такі здібності людини, як креативність, здатність генерувати нові неординарні ідеї і рішення. А виконання рутинних операцій, аналіз великих даних та ін. - справа машини, яка виконає це завдання уже краще за людину.

Ключові слова: штучний інтелект; нейронна мережа; алгоритм машинного навчання; твір мистецтва 


\section{ИСКУССТВЕННЫЙ ИНТЕЛЛЕКТ КАК ИНСТРУМЕНТ ТВОРЕНИЯ И АНАЛИЗА ПРОИЗВЕДЕНИЙ ИСКУССТВА}

\section{Трач Юлия Васильевна}

Кандидат педагогических наук, ORCID: 0000-0003-2963-0500,0411@ukr.net, Киевский национальный университет культуры и искусств, Киев, Украина

Цель статьи - раскрыть специфику создания новых произведений искусства с помощью технологий искусственного интеллекта. Методология исследования основывается на применении диалектического метода с его принципами системности, развития и единства противоположностей, поскольку искусственный интеллект как сложный социокультурный феномен склоняет к формулированию однозначных определений и в то же время требует диалектической трактовки его сущности и очерчивания сфер его применения. Научная новизна полученных результатов состоит в том, что искусственный интеллект рассматривается как составная художественного творчества, одно из заданий которой - введение технических новаций в сферу человеческой культуры. Выводы. Обращено внимание на пребывание вне культурологического дискурса проблематики искусственного интеллекта, тогда как отделение проблемы искусственного интеллекта от культуры неминуемо приводит к упрощенному пониманию последней. Подчеркнуто, что актуальность культурологического исследования искусственного интеллекта определяется распространением симбиозных форм взаимодействия пользователя и глобального программного обеспечения, что требует не столько оценки и исправления негативных последствий распространения технологий, сколько выработки метатехнологии по их предупреждению. Со своей стороны, рефлексия культуры, когда последняя отбрасывает идеи апокалипсиса и восстания машин, может дать толчок к возникновению новых смыслов и перспектив для человека и культуры. Приведены примеры применения технологий (в частности, GAN и CAN) искусственного интеллекта в современном искусстве. Сделан вывод, что чем больше в процессе создания произведений искусства используются технологии искусственного интеллекта, тем больше возрастает ценность идей, концепции. Сегодня, когда исполнение, физическую реализацию проекта, можно «переложить» на искусственный интеллект, именно новые идеи становятся основной движущей силой развития искусства. Генерирование идей может стать главной функцией не человека, а «машины», что в очередной раз доказывает правильность предположения, что с каждым годом более ценными будут становиться такие способности человека, как креативность, способность генерировать новые неординарные идеи и решения. А исполнение рутинных операций, анализ больших данных и т.п. - дело машины, которая выполнит это задачу уже лучше человека.

Ключевые слова: искусственный интеллект; нейронная сеть; алгоритм машинного обучения; произведение искусства 